\title{
DNA Synthesis as a Measure of Bacterial Productivity in Seagrass Sediments
}

\author{
D. J. W. Moriarty and P. C. Pollard \\ Division of Fisheries Research, CSIRO Marine Research Laboratory, P.O. Box 120, Cleveland, Qld 4163, Australia
}

\begin{abstract}
Bacterial growth rates in sediments have been calculated from measurements of the rate of incorporation of tritiated thymidine into deoxyribonucleic acid (DNA). The dilution of isotope in DNA was used to estimate the sum of the pools of thymidine in the sediment and of other cellular precursors of thymidine in DNA. Growth rates of bacteria in the surface zone of seagrass bed sediments varied from $3.7 \times 10^{8}$ cell divisions $\mathrm{h}^{-1} \mathrm{~g}^{-1}$ dry weight of sediment on a hot autumn day to $3.3 \times 10^{6}$ cell divisions $\mathrm{h}^{-1} \mathrm{~g}^{-1}$ in winter. By combining growth rate measurements using the isotope dilution procedure with biomass measurements, it is now possible to obtain reasonably reliable estimates of bacterial productivity in sediments.
\end{abstract}

\section{JTRODUCTION}

Seagrass beds are highly productive plant communities, in which much of the primary production is not utilized directly by animals, but enters higher trophic levels through microorganisms, especially bacteria (Phillips and McRoy, 1980). To quantify this process, we need to know not only the biomass of the bacterial population, but also its growth rate. Methods are available for measuring biomass in these sediments, which show that bacteria in seagrass beds of Moreton Bay, Queensland constitute about $20 \%$ of the sediment organic matter, excluding that which seagrass roots contribute (Moriarty, 1980). The measurement of growth rates of the whole population has not been possible by classical microbiological techniques. By measuring the rate of synthesis of deoxyribonucleic acid (DNA), we hoped to be able to estimate the growth rate of bacteria in the sediment. Bacteria in sediments take up [methyl- ${ }^{3} \mathrm{H}$ ] thymidine (thymine-2deoxyribose: Tdr) and use it for DNA synthesis (Tobin and Anthony, 1978). Fuhrman and Azam (1980) have used the rate of incorporation of $\mathrm{Tdr}$ into DNA in seawater to estimate growth rate of planktonic bacteria. They assumed that by adding a large excess of isotope, the contribution of Tdr from other pools or pathways would be negligible. In fact this may not be the case as Rosenbaum-Oliver and Zamenhof (1972) found that exogenous Tdr contributed only a portion of the Tdr in DNA, varying from $35 \%$ to $63 \%$ in a normal strain of Escherichia coli, depending on the culture conditions. The highest value of $63 \%$ of exogenous Tdr was obtained with $1 \mathrm{mg} T \mathrm{Tr} \mathrm{ml}^{-1}$ of culture medium. If natural populations of bacteria behave similarly, then to estimate the rate of DNA synthesis, and thus obtain the rate of bacterial division, it is necessary to measure the dilution of added Tdr by pools in the cells and in the sediment. Thymidine-5'triphosphate (dTTP), the final precursor in DNA synthesis, is synthesised only partly from exogenous Tdr and partly via other pathways within the cell (Rosenbaum-Oliver and Zamenhof, 1972). An isotope dilution experiment can be used to determine the effect of added 'cold' precursor on the amount of labelled precursor incorporated into a macromolecule (Forsdyke, 1968). In this paper we show how, using this technique, the total sum of pools contributing thymine bases to DNA synthesis may be estimated, and thus calculate the growth rate of the bacterial population.

\section{MATERIALS AND METHODS}

We took a series of cores (25 mm diameter) of sediment from a seagrass bed in Moreton Bay, Queensland (Australia), which was dominated by Zostera capricorni, and combined the top $3 \mathrm{~mm}$. For routine isotope dilution experiments, a series of $25 \mathrm{~mm}$ diameter centrifuge tubes (usually 7 , but more for some experiments) were set up containing $7.4 \times 10^{5} \mathrm{~Bq}(20$ 
$\mu \mathrm{Ci}$ ) of tritiated Tdr. Unlabelled Tdr was added to give a series with the isotope diluted by progressively more $\mathrm{Tdr}$ as shown in the figures. For some experiments, more tritiated $\mathrm{Tdr}$ was used. Portions of the mixed slurry were dispensed with a small plastic spoon into the tubes and incubated at the in situ temperature in a water bath on the boat. The incubation was terminated by addition of $2 \mathrm{ml}$ of $0.6 \mathrm{M} \mathrm{NaOH}$, which gave a final concentration of about $0.4 \mathrm{M} \mathrm{NaOH}$ (we now add $0.6 \mathrm{M}$ $\mathrm{NaOH}$ containing $10 \mathrm{mM}$ Tdr. Sediment was dispensed into control tubes and treated with $\mathrm{NaOH}$ prior to isotope addition. Normally milder conditions for the extraction of DNA have been used (Thomas et al., 1974; Tobin and Anthony, 1978). We found, however, that the more rigorous conditions described here extracted more DNA from these sediments. Samples were heated at $100{ }^{\circ} \mathrm{C}$ for $4 \mathrm{~h}$, centrifuged at $5000 \times \mathrm{g}$ for $10 \mathrm{~min}$ and the supernatants were dialysed c.vel. night against running water, then $100 \mu \mathrm{l}$ of $\mathrm{Tdr}$ and DNA, each $5 \mathrm{mg} \mathrm{ml}^{-1}$, was added. The $\mathrm{pH}$ was adjusted to 0.7 with concentrated $\mathrm{HCl}$. The acidified solutions were cooled for $40 \mathrm{~min}$ on ice and the precipitate immediately collected on a Whatman GF/C filter. After washing with $2 \mathrm{ml}$ cold $5 \%(\mathrm{w} / \mathrm{v})$ trichloracetic acid (TCA) the DNA was hydrolysed in $2 \mathrm{ml} 5 \%$ TCA at $100^{\circ} \mathrm{C}$ for $30 \mathrm{~min}$. After centrifuging, $0.5 \mathrm{ml}$ of supernatant was counted in $4 \mathrm{ml}$ scintillant (PCS II, Amersham Australia Pty Ltd).

Forsdyke (1968), in studying RNA synthesis, showed that the observed counts $(x)$ appearing in a macromolecule were given by the relation $x=n /(p+y+1)$, where $n$ was the maximum count that would be incorporated with no dilution, and $p$ was the dilution factor due to the endogenous pool of precursors, and $(y+1)$ the dilution by the added pool. In the case of DNA synthesis, $(y+1)$ is the dilution by added $T d r$ and $p$ is the dilution by Tdr in the sediment and in the cell. Another factor $(\mu)$ is added to these pools, the contribution from de novo synthesis via deoxyuridine-5' -monophosphate (dUMP). Thus the equation becomes $x=n /$ $(p+y+u+1)$ and is rearranged to give $y+1=(1 / x) n-$ $(p+u)$. Forsdyke (1968) plotted the actual amounts of pyrimidine nucleoside added, rather than the dilution, against $(1 / x)$, but as $1 / x$ is the dependent variable we have plotted it against the amount of $\mathrm{Tdr}$ present. The negative intercept on the abscissa gives the size of the pools that effectively dilute the isotope in dTTP, the final precursor of DNA.

The growth rates $(G)$ of the bacterial populations were calculated from the relation $G=R \times 1.3 \times 10^{18}$, $S A$, where $R=$ rate of incorporation of Tdr into DNA in disintegrations $\min ^{-1}(\mathrm{dpm}) \cdot \mathrm{min}^{-1} \mathrm{~g}^{-1}$ sediment, and $S A=$ the specific activity of the Tdr, corrected for dilution in dpm mole ${ }^{-1}$. The factor $1.3 \times 10^{18}$ was derived from the assumption that thymine constitutes an average of $25 \%$ of the bases in bacterial DNA (range $12 \%$ to $36 \%$ ) and that the genome size is $2.5 \times$ $10^{9}$ daltons (range $1 \times 10^{9}$ to $3.6 \times 10^{9}$, Gillis et al., 1970; Wallace and Morowitz, 1973). Bacterial numbers were counted by direct microscopy (Moriarty, 1980).

\section{RESULTS}

The initial rate of incorporation of Tdr into DNA was linear, indicating that there is very rapid mixing of label with the various pools inside and outside the bacteria (Fig. 1). The linear period was $8 \mathrm{~min}$ for undiluted labelled thymidine in a sample collected in the autumn when water temperatures were high (Fig. 1A) and over $20 \mathrm{~min}$ in at lower temperatures in winter (Fig. 1C). Departure from linearity probably occurred when the adsorption of thymidine onto sediment particles lowered the concentration so that an excess was no longer available to the bacteria. This conclusion is supported by the longer period of linearity that occur-

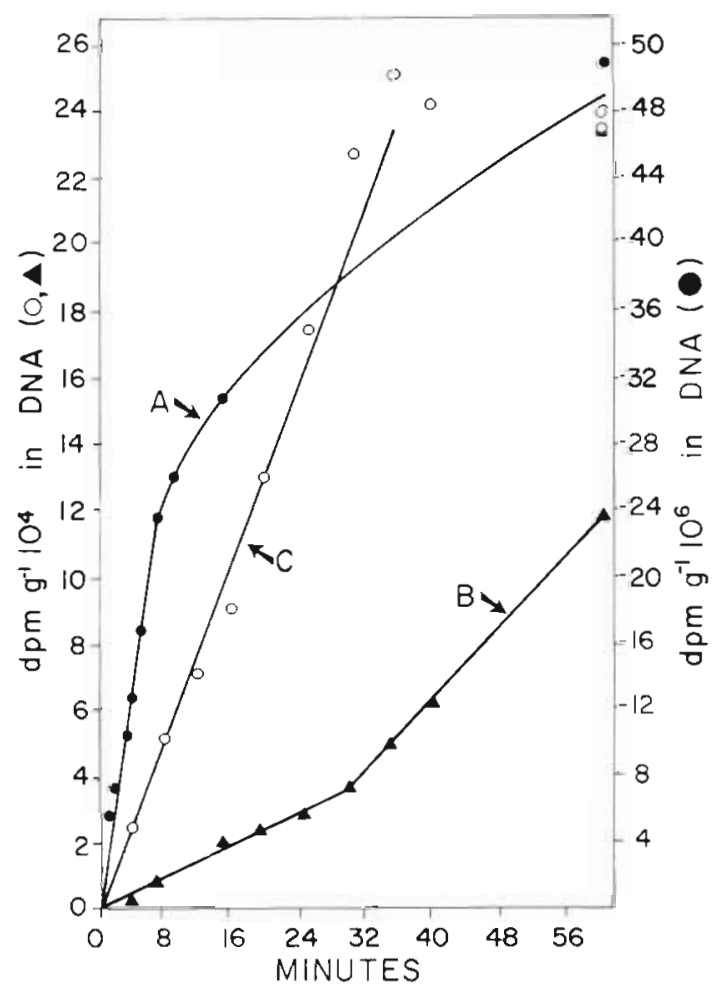

Fig. 1. Time course of incorporation of (methyl- $\left.{ }^{3} \mathrm{H}\right]-$ Thymidine (Tdr) into DNA. A: Autumn samples (water temperature $\left.31^{\circ} \mathrm{C}\right) 1.8 \times 10^{12} \mathrm{~Bq} \mathrm{Tdr}\left(50 \mu \mathrm{Cl}_{1} \mathrm{SA}=1.6 \times 10^{12} \mathrm{~Bq}\right.$ ! mmol). B: Same samples but $1.5 \times 10^{6} \mathrm{~Bq} \mathrm{Tdr}(40 \mu \mathrm{Cl}, \mathrm{SA}=$ $\left.5.9 \times 10^{10} \mathrm{~Bq} / \mathrm{mmol}\right) . \mathrm{C}$ : Winter samples $\left(18^{\circ} \mathrm{C}\right) .7 .4 \times 10^{5} \mathrm{~Bq}$ Tdr $\left(20 \mu \mathrm{C}, \mathrm{SA}=1.6 \times 10^{12} \mathrm{~Bq} / \mathrm{mmol}\right)$. Autumn samples, 4-5 g wet weight of surface sediment slurry, were combined with isotope and held at $31^{\circ} \mathrm{C}$. Incubation was terminated by addition of $2 \mathrm{ml}$ of $0.6 \mathrm{M} \mathrm{NaOH}$. Winter samples, $2.05 \pm$ $0.05 \mathrm{~g}$ wet weight sediment, were assayed at $18^{\circ} \mathrm{C}$ 

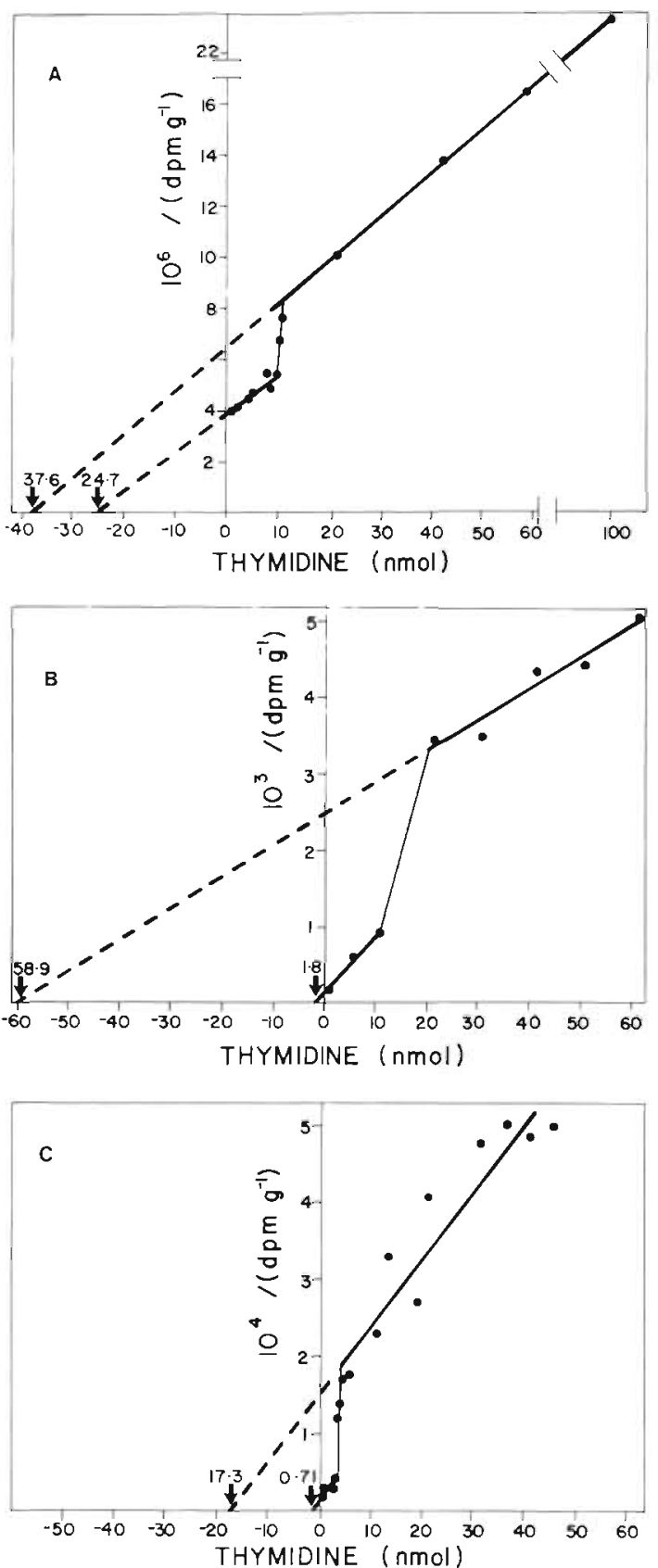

Fig. 2. Isotope dilution plot of incorporation of [methyl $\left.-{ }^{3} \mathrm{H}\right]$ Tdr into DNA. Each sample of $4-6 \mathrm{~g}$ wel weight of sediment incubated with isotope plus added $\mathrm{Tdr}$ for $8 \mathrm{~min}$ at $31^{\circ} \mathrm{C}$. Results from 3 separate sampling occasions. A: $1.8 \times 10^{6} \mathrm{~Bq}$ $(50 \mu \mathrm{Ci})$ isotope added. $\mathrm{B}$ and $\mathrm{C}: 1.5 \times 10^{\mathrm{E}} \mathrm{Bq}(40 \mu \mathrm{C} \mathrm{i})$ isotope added

red when the label was diluted with thymidine (Fig. 1B).

Plots of the dilution of isotope incorporated into DNA by added thymidine indicate that substantial pools of thymidine or other precursors of thymidine-5'-monophosphate (dTMP) are present. Biphasic plots were obtained for three samples, in which two pools of
dTMP precursors are apparent (Fig. 2). Two growth rates were calculated for each of these samples, using the two pool sizes and respective rates of incorporation of isotope. Within each sample, the two growth rates were similar (Table 1). For most samples simple linear plots were obtained, some examples of which are shown in Fig. 3.

It is not possible to estimate the pool size of dTMP precursors using undisturbed cores, because the varia-
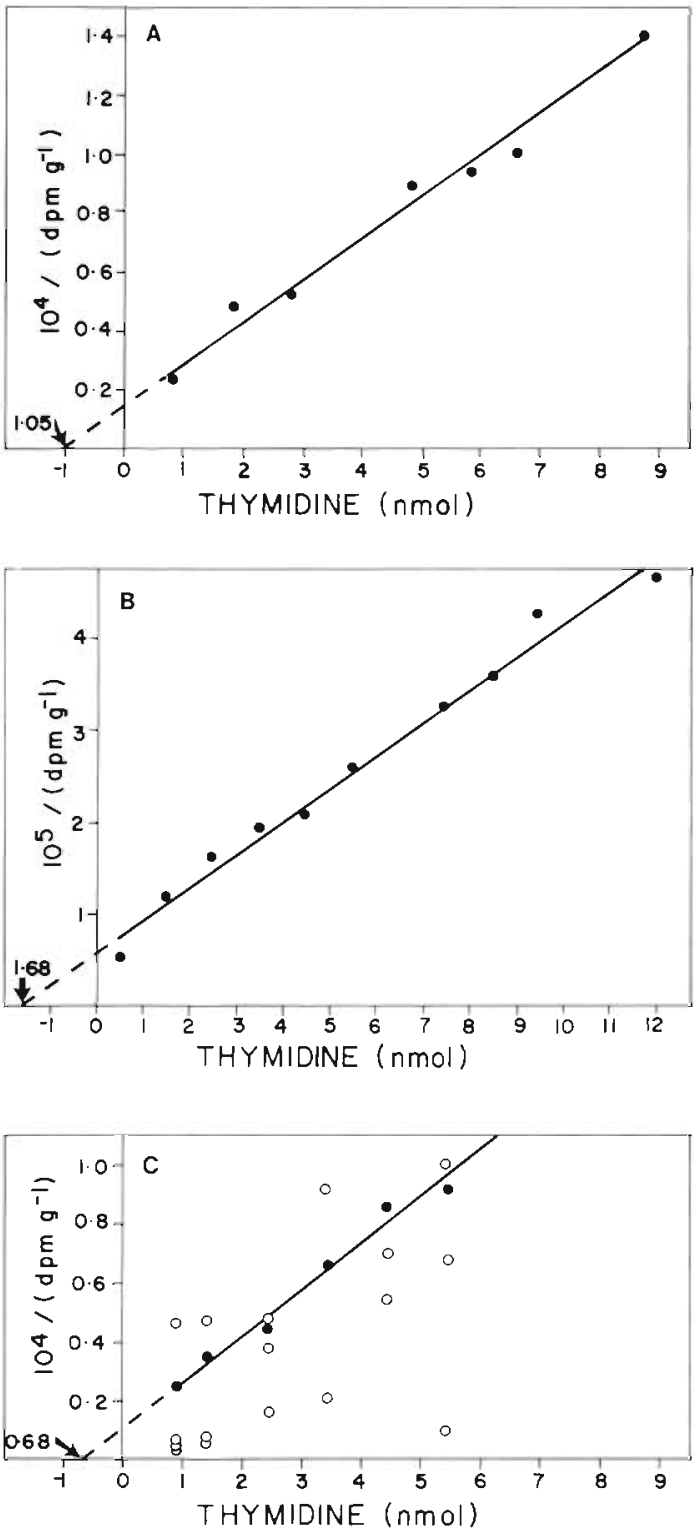

Fig. 3. Isotope dilution plots of incorporation of [methyl- $\left.{ }^{3} \mathrm{H}\right]-$ Tdr into DNA. Each sample of $2 \mathrm{~g}$ wet weight of sediment slurry incubated with isotope plus added $\mathrm{Tdr}$ at ambient temperature. A: $1.3 \times 10^{5} \mathrm{~Bq}(40 \mu \mathrm{Ci})$ isotope incubated for 15 min at $17^{\circ} \mathrm{C}$. B: $7.4 \times 10^{5} \mathrm{~Bq}(20 \mu \mathrm{Ci})$ isotope incubated for 30 min at $18.5^{\circ} \mathrm{C}$. C: closed circles, $7.4 \times 10^{5} \mathrm{~Bq}$ isotope incubated for $15 \mathrm{~min}$ at $24^{\circ} \mathrm{C}$, regression line calculated for closed circles only; open circles, $7.4 \times 10^{5} \mathrm{~Bq}$ isotope incubated with top $3 \mathrm{~mm}$ of individual cores for $15 \mathrm{~min}$ at $24{ }^{\circ} \mathrm{C}$ 
Table 1. Growth rates of bacteria. For each sediment sample shown in Fig. 2, two pools of thymidine were apparent. Growth rates calculated for each are listed as number of cell divisions $\mathrm{h}^{-1} \mathrm{~g}^{-1}$ dry weight of sediment. Tdr $=$ tymine2-deoxyribose

\begin{tabular}{|ccc|}
\hline Sample & $\begin{array}{c}\text { Tdr pool size } \\
\text { (nnol) }\end{array}$ & $\begin{array}{c}\text { Growth rate } \\
\text { (cells h }{ }^{-1} \mathrm{~g}^{-1} \text { ) }\end{array}$ \\
\hline A & 37.6 & $5.2 \times 10^{8}$ \\
A & 24.7 & $2.5 \times 10^{8}$ \\
B & 58.9 & $2.6 \times 10^{6}$ \\
B & 1.8 & $1.5 \times 10^{6}$ \\
C & 17.3 & $1.2 \times 10^{7}$ \\
C & 0.7 & $1.1 \times 10^{7}$ \\
\hline
\end{tabular}

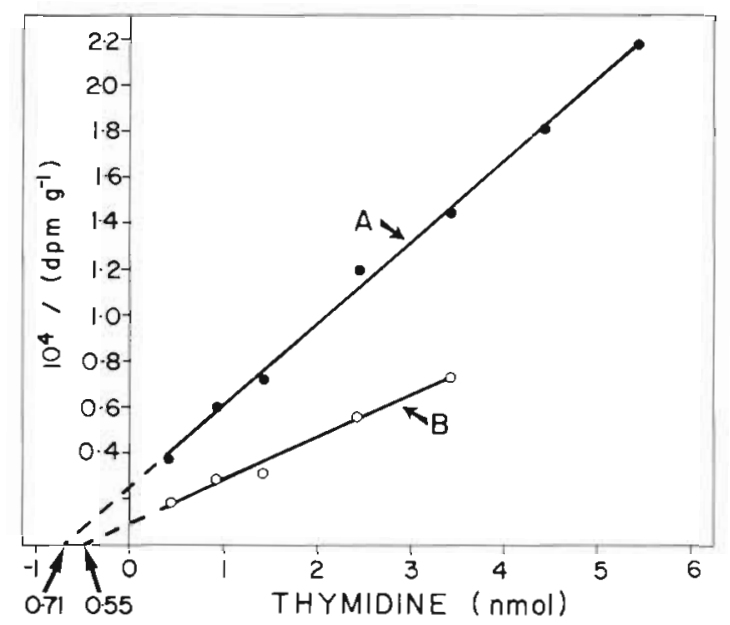

Fig. 4. Effect of delay in analysis on isotope dilution plot. Each sample of $2 \mathrm{~g}$ wet weight of sediment slurry incubated with $7.4 \times 10^{5} \mathrm{~Bq}$ isotope for $15 \mathrm{~min}$ at $20^{\circ} \mathrm{C}$. A: Incubations were carried out immediately after collection and mixing on the boat. B: Incubations carried out after $1 \mathrm{~h}$ on return to the laboratory

bility is too great for a meaningful regression line to be drawn (Fig. 3C, open circles). A precise estimate of pool sizes is possible onl $y$ with a mixed slurry (Fig. 3C, closed circles). The results from this particular experiment demonstrate the patchiness in bacterial activity. It is necessary to carry out the incubation with thym- idine as soon as possible after sample collection. The pool size of dTMP precursors was larger, and the rate of incorporation of Tdr lower in samples that were analysed on the boat immediately after collection, compared to samples that were brought to the laboratory and analysed under more controlled conditions about $1 \mathrm{~h}$ later (Fig, 4). The growth rates of bacteria in the seagrass flat sediments collected in a hot autumn period were two orders of magnitude higher than those collected in winter (Table 2). The turnover time for the whole population varied from about 5 h to over 1 week.

\section{DISCUSSION}

The estimation of bacterial activity or growth rates in natural environments by measurement of the incorporation of tritiated thymidine into DNA has been used and discussed by a number of workers (e.g. Brock, 1971; Thomas et al., 1974; Fuhrman and Azam, 1980). We have assumed that only bacteria were able to utilize nanomolar quantities of Tdr for DNA synthesis in the short time periods of these experiments. In fact, many blue-green algae and small eukaryotic algae and fungi lack thymidine kinase, and thus cannot incorporate Tdr directly into DNA (Grivell and Jackson, 1968; Glaser et al., 1973). Most bacteria probably do contain thymidine kinase, which is a necessary enzyme of the 'salvage' pathway for DNA synthesis (Cleaver, 1967). The de novo pathway proceeds via dUMP to dTMP and thus bypasses thymidine. The interactions between these pathways are complex and may not be the same in all bacteria, so it cannot be assumed that the addition of a large amount of thymidine will lead to a cessation or even a considerable lowering of the contribution of the de novo pathway. The assumption that all bacteria have thymidine kinase is a conservative one. If, as Fuhrman and Azam (1980) point out, some bacteria lack this enzyme, then the productivity estimates will be lower than the actual production. Fuhrman and Azam (1980), in their study of the production of bacteria in seawater, commented that because it was not possible to measure internal

Table 2. Growth rates and turnover times of bacterial populations in seagrass sediments. Growth rates and population sizes expressed per $g$ dry weight of sediment. All experiments were carried out on samples collected in the early afternoon

\begin{tabular}{|c|c|c|c|c|}
\hline Month & $\begin{array}{c}\text { Temperature } \\
\left({ }^{\circ} \mathrm{C}\right)\end{array}$ & $\begin{array}{l}\text { Population growth rate } \\
\text { (cells } \mathrm{h}^{-1} \mathrm{~g}^{-1} \text { ) }\end{array}$ & $\begin{array}{l}\text { Population size } \\
\left.\quad(\text { cells g })^{-1}\right)\end{array}$ & $\begin{array}{c}\text { Turnover time } \\
\text { (h) }\end{array}$ \\
\hline April & 31 & $3.7 \times 10^{8}$ & $2 \times 10^{9}$ & 5.5 \\
\hline June & 18.5 & $4.6 \times 10^{6}$ & $6.4 \times 10^{8}$ & 58 \\
\hline July & 17 & $4.6 \times 10^{6}$ & $6.4 \times 10^{8}$ & 140 \\
\hline August & 20 & $3.3 \times 10^{6}$ & $6 \times 10^{8}$ & 180 \\
\hline October & 24 & $7.3 \times 10^{6}$ & $\times 10^{4}$ & 130 \\
\hline October & 24 & $2.1 \times 10^{7}$ & $1 \times 10^{9}$ & 48 \\
\hline
\end{tabular}


pool sizes, they were making the conservative assumption that the internal pools and the biosynthetic pathways leading to DNA were saturated by the added Tdr. In fact, as Rosenbaum-Oliver and Zamenhof (1972) showed with Escherichia coli, exogenous Tdr contributed only $63 \%$ of thymine bases to DNA when supplied at a concentration of $1 \mathrm{mg} \mathrm{ml}^{-1}$ in the presence of amino acids, and $42 \%$ in the absence of amino acids. Fuhrman and Azam (1980) reported that the dilution of labelled thymine incorporated into DNA appeared to be small. The isotope dilution technique described here, in which the dilution of isotope incorporated into DNA is measured, provides a way to estimate the degree of participation of exogenous thymidine in DNA synthesis. It is assumed that the rate-controlling step occurs after the synthesis of dTMP; if this were not so, then the addition of increasing quantities of $\mathrm{Tdr}$ would not give a linear plot. Rosenbaum-Oliver and Zamenhof (1972) found that the growth rates of 4 strains of $E$. coli were not affected by the concentration of exogenous Tdr. The linearity of the plot shown in the initial minutes of Fig. 1, in each phase of Fig. 2 and in Figs 3 and 4 , indicates that the complex population of bacteria in the sediment can be treated as a single entity. Only the activity of fast growing bacteria is measured with this technique. The turnover times for the whole population are an average of fast growing cells and cells that are not dividing (Table 2).

An interpretation of the biphasic graphs shown in Fig. 2 is that two pools of thymidine or other precursors of dTMP exist in the sediment. This interpretation is supported by the similarity in growth rates calculated for each sample using both pool sizes and the respective rates of isotope incorporation (Table 1). The second pool was exposed at higher concentrations of $\mathrm{Tdr}$, and as this occurred on only three occasions, it is likely to have been a pool in the sediment rather than the bacteria. The demonstration of such large pools means that any comparative study of bacterial activity or growth rates in such environments must take these pools into account, otherwise only the dilution of isotrope rather than a difference in activity of bacteria may be measured.

The procedure that we have described for the isolation of DNA was developed to give maximum recovery of labelled DNA from these sediments, which are mainly sand with some clay and heavy metals. For other sediments and seawater, a lower concentration of $\mathrm{NaOH}(0.3 \mathrm{M})$ should be used. Purification of DNA from other cellular components is necessary, because some isotope was incorporated into other macromolecules. The technique is based on the SchmidtThannhauser procedure (reviewed by Munro and Fleck, 1966). With this method RNA is hydrolyzed and DNA solubilized in a hot alkali solution. Low back- ground levels of radioactivity were obtained when unlabelled Tdr was added and the solution was dialysed. Acidification of the dialysis residue and then hydrolysis of DNA in TCA separates DNA from protein. As Tobin and Anthony (1978) showed, DNA is the only source of label after purification by the above procedure

The accuracy of the growth rate calculations is affected by two assumptions, viz. that thymine constitutes $25 \%$ of the bases in DNA and that the genome size is $2.5 \times 10^{9}$ daltons. If only one or two species of bacteria were actively growing, then the results given in Tables 1 and 2 could be in error by a factor of 2 or 3 . If, however, many species are using the $T$ dr that was supplied, it is likely that the average quantities used above provide a close estimate of the true values. Work is in progress to check $G+C$ ratios of the actively growing cells.

The growth rates obtained for benthic bacteria in the seagrass sediments show considerable variability, some of which is probably a seasonal trend (Table 2). The very rapid growth rates and large pool sizes on the hot April day may indicate a site of rapid decomposition in the sediment. As these values represent only one measurement during the warmest period of day, they cannot be extrapolated to a full $24 \mathrm{~h}$. The turnover times for the bacterial population in the winter months are similar to the value of $91 \mathrm{~h}$ obtained by Meyer-Reil et al. (1980) with an indirect technique, for a microbial population on a sandy beach with a similar temperature regime. Further work is now in progress to assess diurnal and seasonal changes in bacterial productivity. Preliminary results show that there is a large fluctuation in diurnal growth rates in the seagrass beds, which is why it is not valid to extrapolate the results reported here. It is clear, however, that in quantifying the importance of rapidly growing bacterial populations in food chains, measurement of productivity as well as biomass is essential. The biomass of bacteria in sediments generally remains relatively constant, whereas productivity can vary by more than an order of magnitude (Table 2). The difference between the productivity and change in biomass over a given time interval is a measure of the amount of bacteria removed from the system by grazing, or perhaps loss to the water column. The productivity measurements provide a measure of total bacterial activity, unlike assays for heterotrophic activity which measure the activity of that portion of the population that are able to use the substrate provided. Thus it will be possible to investigate processes such as the effect of deposit-feeders on bacterial growth and the proportion of primary productivity that is cycled directly through bacteria to animals. 


\section{LITERATURE CITED}

Brock, T D. (1971). Microbial growth rates in nature. Bacteriol. Rev. 35: 39-58

Cleaver, J. E. (1967). Thymidine metabolism and cell kinetics. In: Neuberger, A., Tatum, E. L. (eds) Frontiers of biology. North-Holland Research Monographs. Amsterdam, pp. $7-259$

Forsdyke, D. R. (1968). Studies of the incorporation of $\left[5-{ }^{3} \mathrm{H}\right]$ uridine during activation and transformation of lymphocytes induced by phytohaemagglutinin. Biochem. J. 107 $197-205$

Fuhrman, J. A., Azam, F. (1980). Bacterioplankton secondary production estimates for coastal waters of British Columbia, Antarctica, and California. Appl. environ. Microbiol. 39: 1085-1095

Gillis, M., De Ley, J., De Cleene, M. (1970). The determination of molecular weight of bacterial genome DNA from renaturation rates. Eur. J. Biochem. 12: 143-153

Glaser, V M., Al-Nui, M. A., Groshev, V. V., Shestakov, S. V. (1973). The labelling of nucleic acids by radioactive precursors in the blue-green algae. Arch. Mikrobiol. 92: $217-226$

Grivell, A. R., Jackson, J. F. (1968). Thymidine kinase: evidence for its absence from Neurospora crassa and some other micro-organisms, and the relevance of this to the specific labelling of deoxyribonucleic acid. J. gen. Microbil. 54 : $307-317$

Meyer-Reil, L.-A., Bölter, M., Dawson, R., Liebezeit, G.,
Szwerinski, H., Wolter, K. (1980). Interrelationships between microbiological and chemical parameters of sandy beach sediments, a summer aspect. Aupl. environ. Microbiol. 39: 797-802

Moriarty, D. J. W. (1980). Measurement of bacterial biomass in sandy sediments. In: Trudinger, P. A., Walter, M. R. Ralph, B. J. (eds) Biogeochemistry of ancient and modern environments. Australian Academy of Science, Canberra and Springer-Verlag, Berlin, pp. 131-139

Munro, H. N., Fleck, A. (1966). The determination of nucleic acids. In: Glick, D. (ed.) Methods of biochemical analysis Interscience Publishers, John Wiley and Sons, New York, London and Sydney, Vol. 14, pp. 113-176

Phillips, R. C., McRoy, C. P. (1980). Handbook of seagrass biology - an ecosystem perspective, Garland STPM Press, New York and London

Rosenbaum-Oliver, D., Zamenhof, S. (1972). Degree of participation of exogenous thymidine in the overall deoxyribonucleic acid synthesis in Escherichia coli. J. Bacteriol. 110: $585-591$

Thomas, D. R., Richardson, J A., Dicker, R. J. (1974). The incorporation of tritiated thymidine into DNA as a measure of the activity of soil micro-organisms. Soil Biol. Biochem. 6: 293-296

Tobin, R. S., Anthony, D. H. J. (1978). Tritiated thymidine incorporation as a measure of microbial activity in lake sediments. Limnol. Oceanogr. 23: 161-165

Wallace, D. C., Morowitz, H. J. (1973). Genome size and evolution. Chromosoma 40: 121-126

This paper was presented by Professor G. Rheinheimer; it was accepted for printing on February 3, 1981 